\title{
Repair, regenerative and supportive therapies of the annulus fibrosus: achievements and challenges
}

\author{
Johannes Leendert Bron - Marco N. Helder • \\ Hans-Jorg Meisel · Barend J. Van Royen • \\ Theodoor H. Smit
}

Received: 21 June 2008/Revised: 9 September 2008/Accepted: 5 December 2008/Published online: 23 December 2008

(C) The Author(s) 2008. This article is published with open access at Springerlink.com

\begin{abstract}
Lumbar discectomy is a very effective therapy for neurological decompression in patients suffering from sciatica due to hernia nuclei pulposus. However, high recurrence rates and persisting post-operative low back pain in these patients require serious attention. In the past decade, tissue engineering strategies have been developed mainly targeted to the regeneration of the nucleus pulposus (NP) of the intervertebral disc. Accompanying techniques that deal with the damaged annulus fibrous are now increasingly recognised as mandatory in order to prevent re-herniation to increase the potential of NP repair and to confine NP replacement therapies. In the current review, the requirements, achievements and challenges in this quickly emerging field of research are discussed.
\end{abstract}

Dedicated to the memory of Prof. Dr. Paul I. J. M. Wuisman.

J. L. Bron · M. N. Helder · H.-J. Meisel · B. J. Van Royen

Department of Orthopaedic Surgery,

VU University Medical Center, Amsterdam,

The Netherlands

e-mail: jl.bron@vumc.nl

T. H. Smit $(\square)$

Department of Physics and Medical Technology,

VU University Medical Center, Post Box 7057,

1007 MB Amsterdam, The Netherlands

e-mail: th.smit@vumc.nl

J. L. Bron - M. N. Helder - B. J. Van Royen - T. H. Smit

Skeletal Tissue Engineering Group Amsterdam

(STEGA Foundation), Research Institute MOVE,

Amsterdam, The Netherlands

H.-J. Meisel

Department of Neurosurgery, BG-Clinic Bergmannstrost,

Halle, Germany
Keywords Annulus fibrosus Herniation Discectomy Repair Regeneration

\section{Introduction}

Lumbar discectomy is an effective therapy for neurological decompression in patients suffering from an herniated nucleus pulposus (HNP), which can be safely performed via minimal invasive procedures $[44,128]$. Current discectomy procedures, however, are not directed to treat the damaged intervertebral disc (IVD) and may even further aggravate existing damage $[16,22,45]$. It is therefore not surprising that successful neurological decompression is often followed by periods of persisting low back pain, severely affecting the quality of life [7, 8, 45]. Another serious problem in these patients is the high recurrence rates after discectomy, affecting up to $15 \%$ of the patients $[7,8,16,23,42,59,63,66,98,113,115]$. Since discectomy is still the most performed spinal surgical procedure worldwide and mainly affects the employed population, the resulting socio-economical consequences are dramatic [61]. This gives investigators the impetus to search for new strategies that also deal with the damaged IVD in patients treated for HNP [68, 74, 105].

During the last 5 years, increasing knowledge and technical advancements in the field of tissue engineering has resulted in numerous promising strategies to repair, replace or regenerate the herniated nucleus pulposus (NP) $[45,105]$. None of these advancements, however, has yet resulted in a clinically proven effective therapy. One of the major limitations is the lack of effective strategies that deal with the damaged annulus fibrosus (AF) [125]. Since optimal regeneration of the NP should lead to restoration of the physiological intradiscal pressure, the surrounding $\mathrm{AF}$ 
is generally of too inferior quality to withstand these forces. Without sufficient attention to the damaged AF, these treatments might be condemned to fail $[5,125]$. Therefore, intervertebral disc engineering strategies are increasingly focusing on the regeneration or repair of the AF in order to reduce the number of re-herniations, increase the potential of NP engineering strategies and to mechanically assist NP replacement therapies $[6,125]$. In the current review, we will discuss the requirements, achievements and challenges in this rapidly emerging field of research.

\section{Anatomy}

Structure of the annulus fibrosus

The IVD is confined by the two cartilage endplates and is composed of two distinct structures, the nucleus pulposus (NP), and the surrounding annulus fibrosus (AF) $[53,130]$. Although the two cartilage endplates offer anatomical limitation to the vertebral bodies, morphology along the plate is distinguished by a central articular-like cartilage under the NP and a peripheral fibrocartilage appropriately associated with the AF. During embryogenesis, the AF develops from the mesenchyme, whereas the NP is derived from the notochord [120]. The AF consists of water (65$90 \%$ ), collagen (50-70\% dry weight), proteoglycans (10$20 \%$ dry weight) and noncollagenous proteins (e.g. elastin) $[14,114]$. The AF has a laminate structure consisting of a minimum of 15 (posterior) to a maximum of 25 (lateral) concentric layers [71]. The layers are composed of type 1 collagen fibres that alternate in angles from $28^{\circ}$ (peripheral AF) to $44^{\circ}$ (central AF) with respect to the transverse plane of the disc $[17,71,84]$. The spaces between the separate layers of the AF are called interlamellar septae, and they contain proteoglycan aggregates and a complex structure of linking elements creating interlamellar cohesion $[14,89$, 111]. At the periphery, some of the annulus fibres pass the endplates to penetrate into the bone of the vertebral body as "Sharpey's fibres" [57]. Central fibres either insert into the cartilage of both endplates or bend with the NP (Fig. 1). The highly organised structure of the AF results in a complex anisotropic behaviour, with the tensile, compressive, and shear properties differing in the axial, circumferential, and radial directions [11, 106, 114]. Based on structural and cellular differences, the AF can be further distincted into an inner and an outer part (Fig. 2) [14, 15, 71, 114]. The inner AF is a broad transition zone between the highly organised collagenous structure of the outer AF and the highly hydrated NP and consists of a mixture of extra cellular matrix (ECM) components of both $[20,130]$. The inner AF is less hydrated than the NP and the layers are more widely spaced compared to the outer AF [52].

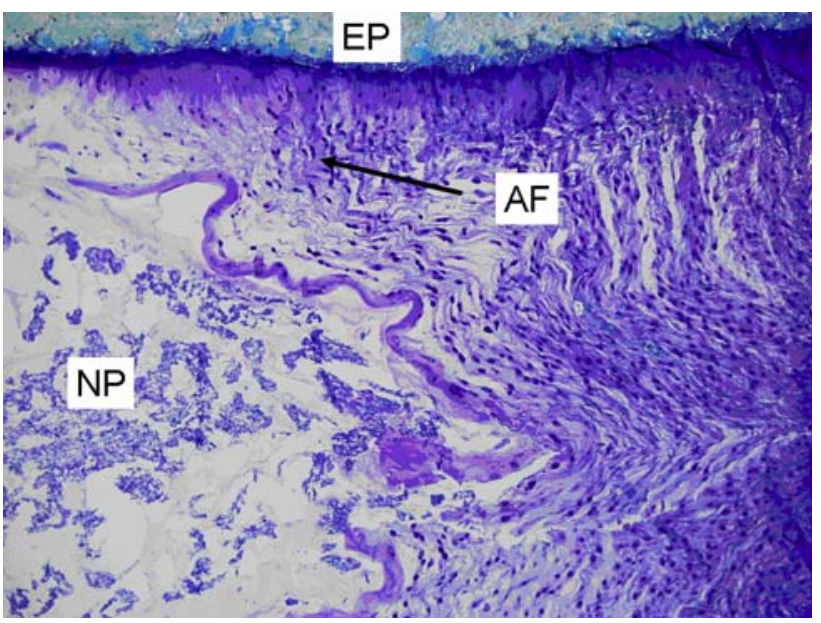

Fig. 1 Histological image (toluidine blue) of the canine intervertebral disc revealing the relation between the nucleus pulposus $(N P)$, annulus fibrosus $(A F)$ and endplates $(E P)$. Some of the most central AF fibres bend with the NP (arrow)

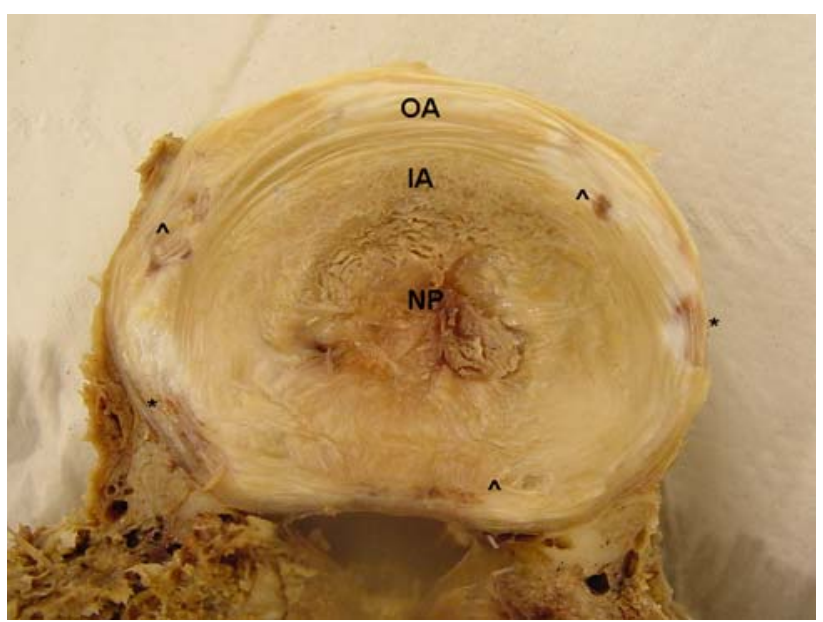

Fig. 2 Saggital section specimen of the L3-L4 intervertebral disc of a middle aged asymptomatic male subject. $N P$ nucleus pulposus, $I A$ inner annulus fibrosus, $O A$ outer annulus fibrosus. Defects in the outer annulus (asterisk) and tears (hat symbol) are visible in the outer annulus, without a sign of herniation. The NP has a severely dehydrated appearance due to conservation techniques

Mechanically, the inner AF is more subjected to the high hydrostatic pressures of the NP than to the tensile forces in the outer AF [73, 112]. These differences have major consequences on ECM synthesis and turnover [52]. The proportion type 1 collagen increases from the inner part towards the outer annulus, whereas type II collagen follows a counterwise distribution $[14,20,122,130]$. Other proteins that have a specific distribution include decorin and biglycan (mainly outer AF) and collagen type $\mathrm{X}$ [inner AF and (aged) NP] [55]. Elastin constitutes 2\% of the dry weight of the AF, but plays an important role in the recoil properties of the AF $[97,129]$. In the outer AF, long elastic 
fibres are present within the lamellae, running parallel to each other and into the same direction as the collagen bundles. In the inner AF, the fibres are present between adjacent lamellae as well as more regularly organised within the lamellae [129]. These fibre networks couple adjacent lamellae together allowing them to work cooperatively during dynamic loading and prevent separation of lamellae during torsional compressive loading [76].

\section{Annulus fibrosus cells}

In mature subjects the cell density in the $\mathrm{AF}$ is about $9 \times 10^{6}$ cells $/ \mathrm{cm}^{3}$, which is over two times higher as compared to the NP [98]. Although all cells in the AF are derived from the mesenchyme, cells within the layers of the $\mathrm{AF}$, the interlamellar spaces and the inner AF have their own morphology and synthesize a distinct ECM [14, 28, $52,71,90,98,130]$. The cells experience not only differences in mechanical environment as described above, but also a rise in $\mathrm{pO}_{2}$ and $\mathrm{pH}$ and a decrease in hydration from the central NP to the outer layers of the AF [50, 52, 94, 98, 118]. In the layers of the outer annulus, fusiform shaped cells, aligning with the collagen fibres and alternating with each lamella are found $[71,90,106]$. In the periphery of the outer annulus, these cells are interconnected by very long processes which results in a continuous communicating network $[14,77]$. The processes are gradually reduced in length and increased in thickness towards the inner AF. In the most central part of the outer AF, the cells are completely isolated without any apparent physical, intercellular connections [14]. These outer annulus cells mainly produce type I collagen [130]. The cells in the interlamellar septae have a more flattened, disc-shaped morphology that show many similarities to the cells of the NP [14]. The predominant cell morphology in the inner annulus consists of spherical shaped cells with one or two short processes, having the highest frequency at the border with the NP [14]. These chondrocyte-like cells in the inner annulus mainly produce type II collagen. A recent study showed that cells derived from the human AF were able to differentiate into the chondrogenic and adipogenic lineages [95]. This suggests that cells in the AF could be skeletal progenitor cells that could be recruited under pathologic conditions such as herniation. Otherwise, progenitor cells from surrounding tissue might perhaps be capable to migrate into the intervertebral disc in the circumstances.

\section{Pathophysiology}

Tissue retrieved from a herniated disc is more often vascularised and is more highly innervated than healthy tissue [97]. Not surprising, this variant morphology also demonstrates a proclivity to MMP and cytokine expression, each of which would be expected to contribute to further re-modelling [97]. Besides these clearly pathologic conditions, other structural changes do occur during ageing that are to certain extent physiological but might have consequences for its strength (Fig. 1.). In the ageing $\mathrm{AF}$ of rats, the number of distinct layers was found to decrease gradually and this loss of volume is compensated by increasing thickness of individual layers and thickening of the inner annulus [90]. In addition, the fibre bundles within the layers become more irregularly distributed with increased interbundle spaces [90]. The loss of distinct layers carries with it the inability for a sustained response to loading and support $[1,41]$. Due to dehydration of the inner annulus, the compressive load is insufficiently converted in the integral of progressive recruitment of tensile support. The lack of annular tone in the degenerated disc results in a lag of mechanical conversion and the annulus comes under the force of axial compression, further reducing the anisotropic capacity for deformation in the normal, healthy disc [2, 49]. These changes have most significant impact on the posterolateral location of the AF, that has the highest frequency of layer interruption [71, 110]. This is also the region where the highest stresses are observed during loading [26] and where annular tears, fissures, protrusions, extrusion and/or sequestrations may develop [86]. Annular tears are seen in more than half of the patients in early adulthood and are invariably present in the elderly (Fig. 1) [119]. The degree of degeneration varies between subjects, for which genetic en environmental (e.g. physical loading, smoking) factors are held responsible [10, 13, 81, 88]. Patients with a genetic predisposition are more prone to disc degeneration under repeated mechanical loading [10].

The relation between loading and degeneration of the AF has been studied by several authors, but our knowledge is still only fragmented. Elverfig et al. [27] showed that shear stress increased the intracellular calcium concentration in AF cells. The sensitivity for shear stress was increased in the presence of the inflammatory cytokine II-1 [27]. Rannou et al. [92] showed that static compression resulted in a significant increase of apoptotic cells in the inner AF in a mouse model. The authors also found an increased caspase- 9 activity and decreased mitochondrial membrane potential following overload, suggesting that degeneration might be mediated through the mitochondrial apoptotic pathway [91]. Furthermore, vibratory loading has been associated with the activation of signalling pathways that regulate ECM destruction in the IVD [127]. Yamazaki showed that gene expression in AF cells for key ECM components such as aggrecan and type II collagen was suppressed following vibratory loading [126]. Lastly, cyclic tensile stretch was found to regulate the ECM by 
decreasing proteoglycan production through a post-translational regulation involving nitrite oxide [92].

Gruber et al. hypothesized that the well-recognised reduction in cell number in the AF during ageing is an important factor for degeneration. This should result in a loss of cell-cell communication and hence a disruption of coordinated cell function [40]. Finally, many adult IVD's show signs of dehydration and "brown degeneration", which is the result of post-translational collagen modification resulting in the formation of chromophores [83, 104]. In these discs, accumulated or enhanced oxidative stress of matrix proteins has resulted in glycoxidation of proteins [83]. Advanced glycosylation end products are further processed to carboxymethyl-lysine by free oxygen radicals, which can be detected by antibodies and used as a biomarker for oxidative stress [82].

\section{Intrinsic healing potential}

The intrinsic capacity of the AF to cope with damage or degenerative changes has been studied in several animal studies [3, 29, 34, 43, 62, 75, 79, 85, 99, 109]. Key and Ford [62] studied the healing capacity of three different types of posterior annulus lesions in a dog model. The lesions included a square annular window, a transverse incision and puncture with a 20-gauge needle. At follow up, they found that the lesions were initially filled with extravasated blood, fibrin, bone and cartilage debris that was gradually replaced by a thin layer of fibrous tissue at later time points (up to 22 weeks). Some of the levels within the window and incision lesion group developed slowly progressive disc protrusion, which was most common in the transversely incised discs. The levels that underwent needle puncture revealed nothing abnormal and the site of puncture could not be identified after 22 weeks. A recent study, however, with rabbit discs in an organ culture model showed that needle puncture has immediate and progressive mechanical and biologic consequences that may lead to degenerative remodelling [65]. The findings of Key and Ford have been underscored and complemented in many studies afterwards [29, 43, 85, 97]. Smith et al. [109] further specified the healing process in three different phases. During the first phase, the outer AF heals, caused by a proliferative reaction in the fibrous tissue spreading from the lateral parts of the wound to the median parts. In the second phase, starting after a few weeks and lasting up to one year post-operative, changes occur in inner annular fibres. Similarly to the outer AF, the lateral parts of the inner AF layers gradually heal by a slow appositional spread in the median direction. During the last phase, there is an increase in the number of collagenous fibres in the NP tissue that has remained in the $\mathrm{AF}$ wound tract, which becomes increasingly dense [109]. Similar findings were more recently obtained in sheep and dog studies $[43,85]$.

From the studies performed thus far it can be concluded that he AF has only a very limited regenerative capacity after annulotomy. Depending on the technique that is used, healing results in a thin layer of biomechanical inferior fibrous tissue [31]. One of the reasons for the limited healing capacity may be the fact that exterior repairs are not matched, or insulated to the demands of progressive recruitment of fibres to tensile force [41, 54]. The mechanical basis for shifting axial loading to circumferential tension requires that the nucleus volume remain elastic, deformable and contained. When the lateral aspects of the annulus are violated, or scarred the ability of the fibres to adequately contain the nucleus changes. In the case of static patient posture and prolonged loading, the disc will experience creep that is proportional to the stage of disc degeneration. In practice, disc degeneration results in a stiffer matrix that does not accommodate the modelling of a disc with normal morphology. If it is not possible to reduce the axial load, then the inevitability of sustaining increasing force in a stiffened matrix will lead to accelerated herniation and more rapid propagation of anular fissures [80]. Independent provinces of repair must therefore be placed in series to expect integration rather than in parallel plots where each will be insufficient to orchestrate the repair separately.

\section{Surgical strategies}

The limited intrinsic healing capacity of the AF negatively affects the success rates of discectomies and NP replacement therapies. It also decreases the potential of intervertebral disc regenerative strategies. To dissolve this problem, attempts to preserve, repair, reinforce or regenerate the $\mathrm{AF}$ in addition to these surgical techniques are desired.

Annulus closure techniques

The most straight-forward solution is per operative suturing of the annular defect and this has been studied by Ahlgren et al. [3] in a sheep model. Although they found that sutured discs showed a tendency towards stronger healing, this was not significant [3]. Unfortunately, no further studies on this subject have been reported. The Xclose ${ }^{(0)}$ and INclose ${ }^{\odot}$ implants are now commercially available for annuloplasty and can be seen as modified sutures with anchors $[12,18]$. Sutures, however, are fully directed to containment of the NP (replacement) and do not compensate the loss of annulus material nor reverse the biomechanical changes that have occurred in the damaged 
AF. The Barricaid $^{\odot}$ is a commercial available implant used in adjunction to discectomies that fully bridges the defect in the AF [36]. This implant even reinforces the complete posterior annulus and would therefore even prevent contralateral herniation. Several other novel suture, seal and barrier techniques are currently being developed, resulting in an increasing attention at scientific workshops and conferences [9, 12, 16, 18, 36, 60, 108, 117]. More detailed analyses are therefore expected in peer reviewed journals in the near future. The momentum of acceptance, however, needs to be balanced in the proof of principle. Risks imposed by criticism need to be weighed in both short- and long-term successes. Clinical durability is the eventual arbiter of technology value, and open trials with clear data will be required.

\section{Regenerative strategies}

Regeneration of the damaged AF is an attractive concept, since it allows restoration of all functions of the AF, but is exceptionally complex to achieve. Regenerative strategies can be divided into cell therapy, gene therapy and tissue engineering with scaffolds [45]. In case of the AF, however, direct mechanical strength and a certain volume to patch the defect seem required in order to contain the NP [125]. Ideally, it should combine direct closure of the defect as discussed in the preceding chapter with the potential for regeneration. Cell and gene therapies are therefore not suitable as standalone therapies, but should be combined with scaffolds. Below, these strategies are first discussed separately, followed by an overview of the studies performed with the necessary scaffolds.

\section{Annulus cells}

Annulus fibrosus cells that are used for AF tissue engineering are derived from humans or various other species (Table 1). The use of human disc cells as a cell source for tissue engineering is difficult because normal healthy disc tissue is not available for such a treatment strategy. In previous studies with tissue derived from herniated discs, an increased degree of cell senescence was found that accumulates over time [38, 96], thus hampering the applicability of this cell source for regenerative strategies [38]. Furthermore, isolation of the cells retrieved from human discectomy material does usually not allow division between inner and outer AF cells. Therefore, cells used for studying annulus regeneration are often harvested from IVD's from healthy small animals. To increase cell number, the AF cells are cultured in vitro first. These cells are isolated from native tissue and it is therefore important to realise that the environment differs greatly from that in situ. Cells no longer have processes, a pericellular matrix and are isolated from each other, and are cultured in gels that do not always allow cellular sliding [25]. Annulus cells have shown to lose their phenotype during two-dimensional (2D) culturing. Chou et al. [20] showed that up to passage two, both inner and outer annulus cells are not different from freshly isolated cells. At later passages, however, both cell types became indistinguishable fibroblast-like with similar type I collagen expression and protein elaboration. The negative effects of monolayer culturing is currently further investigated with specialised 2D environments like collagen coatings, well inserts, or micro-grooved polycaprolactone membranes [21, 37, 58].

To prevent the loss of their phenotype, AF cells are usually cultured in three-dimensional (3D) environments, such as alginate, agarose or collagen hydrogels $[4,37,39$, 64, 100, 130]. Chou et al. [21] found NP and inner and outer AF cells to adopt similar phenotypes after two weeks of culturing in alginate. NP cells and AF cells displayed a rounded chondrocyte-like morphology, expressing high levels of type II collagen versus type I collagen and accumulation of sulphated GAG's. Indeed, the adopted phenotypes are typically NP-like and it was not investigated by these authors whether the changes are reversible [21]. Gruber et al. assessed the ECM expression of AF cells in different 3D culture environments including collagen sponge, collagen gel, agarose, alginate and fibrin [39]. Collagen sponges supported the most abundant ECM formation, whether the ECM production was nearly absent in fibrin gel. The ECM production, however, included types I and II collagen, aggrecan and chondroitin-6-sulfotransferase for all carriers and is this is not specific for AF cells. Moreover, although alginate might be appropriate for inner AF cells, outer AF cells do not survive well in alginate and show a different morphology and matrix expression as observed in vivo [52]. It can be concluded that the appropriate culture environment for AF cells has yet to be elucidated.

AF cells are very prone to pressure effects during culturing and this might be useful for tissue engineering strategies. Reza et al. [93] cultured inner and outer AF cells in PGA scaffolds to evaluate the effect of dynamic hydrostatic pressures (HP). Type II collagen production was enhanced in both cell types by the application of HP. This effect, but also the effects on ECM elaboration and organization, was more pronounced in the scaffold seeded with outer AF cells [93]. The value of these results for $\mathrm{AF}$ engineering however, may be questioned, since AF cells in vivo are more subject to tensile and shearing forces and mainly produce type I collagen. An attractive alternative, that would prevent the problems regarding senescence, limited supply and culturing of autologous AF cells, would be the use of mesenchymal stem cells $[30,51]$. There are 


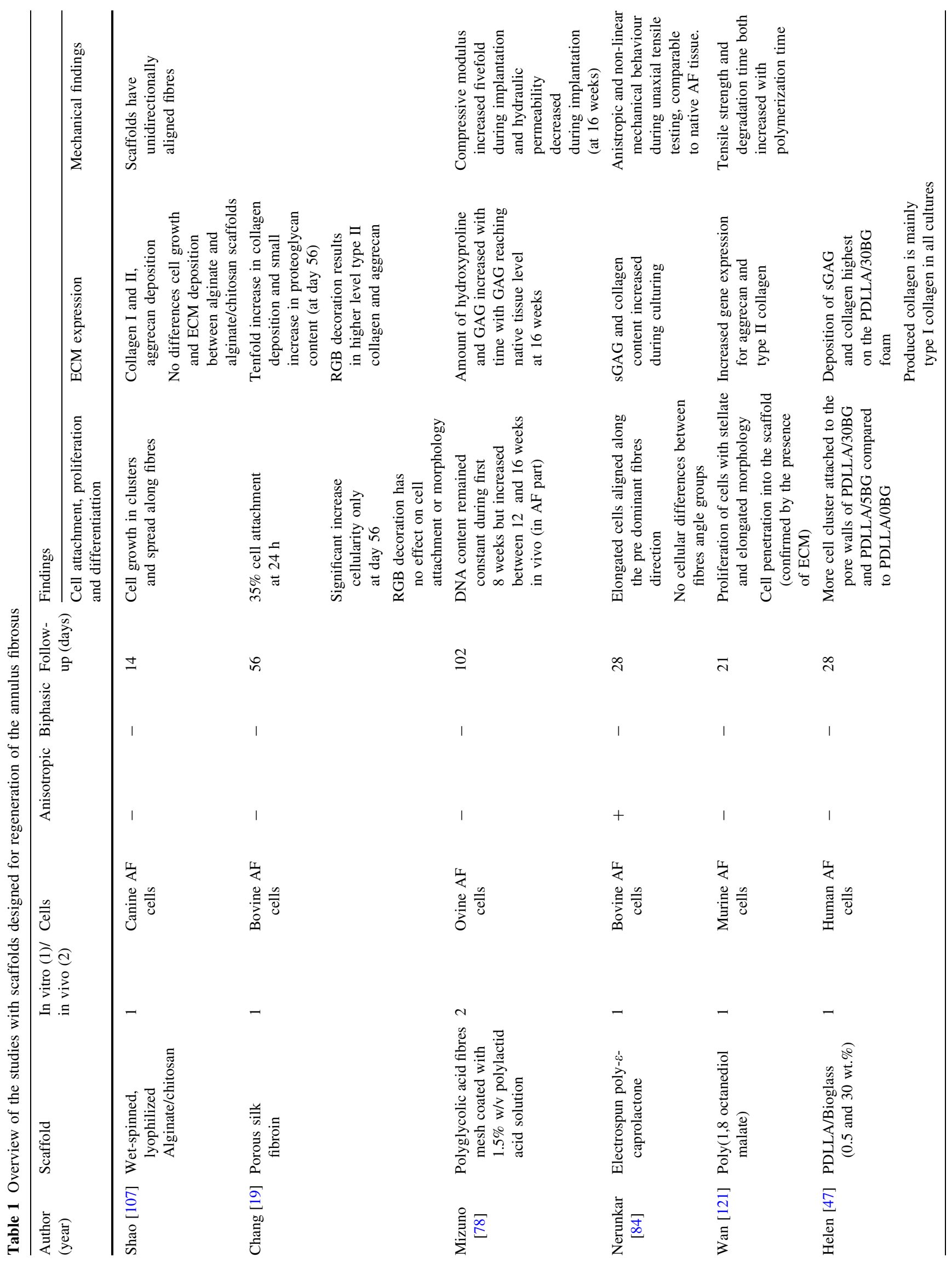




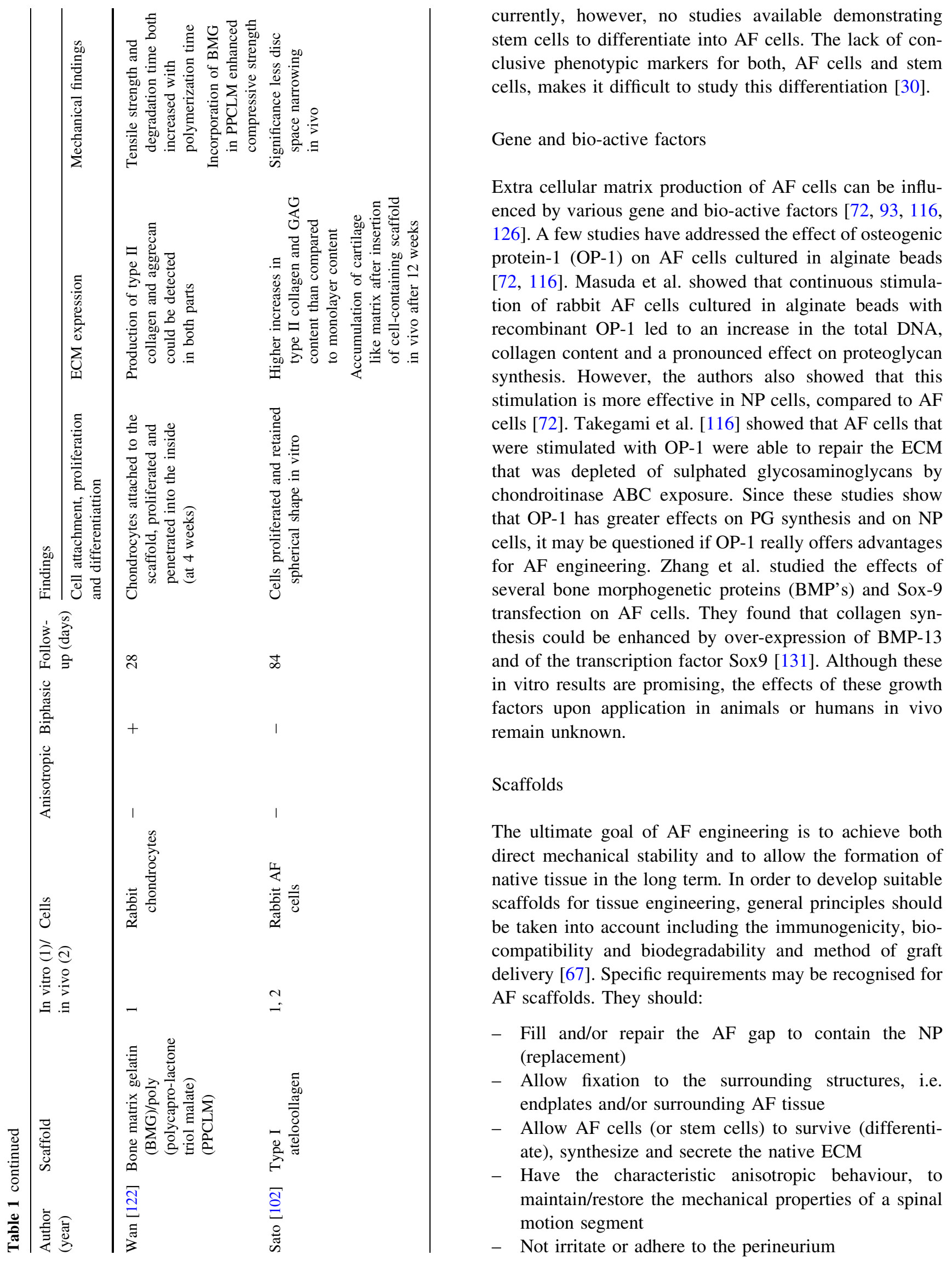


Several scaffolds that could be used for AF tissue engineering have been proposed and evaluated in in vitro or in small in vivo studies. In Table 1 these studies are summarised, as well as to which extent they meet the aforementioned requirements. Without exception, strategies for delivery and fixation in vivo are lacking. Accurate mechanical characterizations are sparse. Only one study reported of a scaffold materials showing anisotropic behaviour, comparable to the AF [84]. However, since collagen sensitivity to lack of tension upregulates collagenase, and has been shown to be a factor specific in regulating cytokine activity, this factor requires further study $[24,35]$. The biphasic appearance of the native AF has also been targeted by a single study. In this study, the inner and outer $\mathrm{AF}$ were simulated by bone matrix gelatine (BMG) and poly-caprolactone triol malate, respectively [122].

In general, these studies have been designed to investigate cell attachment, morphology, proliferation and ECM production on the scaffolds. Native outer AF cells have a typical elongated shape and this is observed in most scaffolds [47, 84, 107, 121]. Shao and Hunter, however, found spherical shaped cells in their scaffolds that agree with an inner AF cell morphology. Interestingly, most studies report of the production of type II collagen and aggrecan $[19,78,84,102,107,121,122]$, instead of collagen type I [47, 48, 107, 124], while the latter is by far the most common ECM component of the AF. Ideally, the cells are seeded in scaffolds in a way they are equally distributed through the scaffold. The disadvantage of the silk and BMG scaffold is that the cells only can be seeded on top and invasion occurs only slowly [19, 122]. Chang et al. tried to improve cell attachment onto the silk scaffold by chemically coating the scaffold with the integrin binding motive RGD. RGD, however, did not result in enhanced cell attachment, but did result in higher levels of type II collagen and aggrecan [19]. Higher levels of type II collagen is an insufficient bridge to repair. Given the fact that type II collagen does not bundle or form fibrillated structures, expression obtained by using RGD peptides may be questioned. Using decorin, or small proteoglycans, which have known function is appropriately binding TGF$\beta$ might be a separate consideration [70]. A critical structural entity of the annulus structure is the network of type I collagen forming fibrils oriented in sheets around the nucleus. A number of molecules present in the matrix regulate and direct the collagen fibril assembly by interacting with the collagen molecule and also the formed fibril. Several of these molecules bind by one domain to the collagen fibre and present another functional domain to interact either with other fibres or with other collagen matrix constituents such as type VI collagen. In this manner the collagen fibres are cross-linked into a network that provides tensile strength and distributes load over large parts of the AF. Assembly occurs both by end-to-end and side-to-side associations. This process is catalyzed by both biglycan and decorin, where the combined effect of direct binding of the core protein to the collagen- $6 \mathrm{~N}$ terminal globular domain and the presence of the glycosaminoglycan side chain is essential. Diminished function in these cross-bridging molecules will lead to loss of mechanical properties of the collagen network and result in an impaired ability of the AF to resist forces delivered by compression of the disc and particularly the nucleus. Decorin has been shown in other systems to retard the TGFbeta affected fibrotic pathway and as such might limit fibrous scarring and impose tissue specific remodeling [32, 56].

Translation from in vitro results to the in vivo situation is difficult and the few studies that have assessed the scaffolds in vivo do provide important additional information. Mizuno et al. [78] implanted complete tissue engineered IVD constructs consisting of calcium alginate discs surrounded by a polyglycolic acid (PGA) ring seeded with $\mathrm{AF}$ cells in the dorsum of athymic mice. The tissue that was formed after 12 weeks follow-up tissue did not resemble native AF tissue with alignment of cells and tissue. Cell proliferation and viability was not quantified in this study. Sato et al. performed laser vaporization in rabbits and the lacunas in the NP and hole in the annulus were filled with an AF cell seeded atelocollagen honeycombshaped scaffold with a membrane seal (ACHMS-scaffold) [101-103]. They found a marked accumulation of cartilage like matrix inside and around the scaffold, which was histologically comparable to native AF tissue [102]. Although this combined NP/AF concept seems promising, it might be questionable if this technique is also feasible to be used to fill larger annulus defects. Novel strategies for delivery and fixation may be required.

\section{Alternative therapies}

Wang et al. simulated a herniation in a swine model and delivered gelfoam, platinum coil, bone cement and tissue glue into the discs. Analysis was performed after two months by quantitative discomanometry. The gelfoam proved best in maintaining disc integrity with resistance to significant higher intradiscal pressures compared to the other groups. The gelfoam group was the only group that was not significantly weaker compared to the intact disc group. The authors conclude that gelfoam may be a potentially clinical applicable method to prevent re-herniation [123]. However, although the foam is safe to use according to the authors, it may be questioned how effective this method is in preventing re-herniation in larger 
annulus defect than the 18 gauge lateral needle hole in the presented animal model.

\section{Discussion}

The research on the AF as a target for novel therapies has only just started to evolve. There are several limitations and pitfalls in the research thus far that should be noted. Experimental AF lesions are generally made at the (antero)lateral region of healthy AF's (Fig. 2) and extrapolation of these studies to humans is difficult [87]. Repair mechanisms in animal studies may differ compared to patients with HNP due to the pathophysiological changes within the IVD that have occurred in the period prior to HNP (Fig. 1) [16]. Furthermore, it is important to realise that annulus fissures commonly develop bilaterally [2]. When successful patching of an AF defect allows restoration of the physiological high intradiscal pressures, the contralateral fissure may progress and become symptomatic. Complete annulus and nucleus tissue engineered constructs as for example of Mizuno et al. would offer a solution for this, but are even more difficult in terms of implantation.

There are striking discrepancies between AF closure techniques and regenerative strategies. Closure techniques are primarily focussing on restoration of the mechanical integrity of the AF and do offer clear solutions for delivery and fixation. These developments are mainly practised in vivo and scientific data is only sparse. Regenerative therapies, on the other hand, target the engineering of healthy and functional AF tissue, but lack strategies for implantation and fixation and thus for clinical application. Of course, a combination of strategies that offer direct mechanical stability and potential for remodelling AF tissue would be preferred.

\section{Future research}

Now that the need for AF repair is increasingly recognised, many studies on this subject are expected to be reported in the scientific literature in the upcoming years. Both AF and NP engineering research are still in very early stages and combined repair strategies should be attempted. Patients undergoing discectomy should ideally benefit from a complete concept in which in one surgical procedure the neurological structures are decompressed and the damaged NP and AF are treated. The increasing knowledge on degradable (bio) polymers offers very encouraging future perspectives [69]. Regenerative matrix scaffolds, biopath materials, memory polymers, disc foams and synthetic gels to translate axial loads, and bioactive hybrid polymers with differential sacrifice to generate cyclic loading during integration efforts might open new paths to successful treatment of patients suffering from disc herniation. These therapies might be further potentiated when combined cell supplementation, bioactive factors and cytokine modulation. The important role of mechanical loading in addition to IVD engineering is yet underexposed. The use of an interspinous implant for example, to favourably alter the motion, in addition to novel IVD engineering therapies in patients undergoing lumbar discectomy deserves attention [33].

AF cells are a phenotypically heterogeneous cell population. In many studies these differences are disregarded and a mixture of AF cells is used. If we could reveal the exact circumstances under which these cells elaborate, we might substitute these different cell types by stem cells and stimulate them to differentiate into all native cell types [46]. This should further prevent the inconveniences in the harvesting and culturing procedures needed for AF cells.

\section{Conclusion}

Intervertebral disc regeneration offers promising perspectives for patients suffering for low back pain due to disc herniation treated with lumbar discectomy. Thus far, efforts for novel therapies have mainly been directed towards replacement or regeneration of the NP. The real challenge, however, might be the development of strategies that deal with the damaged AF, preferably in a combined approach with the NP. Regenerative therapies of the AF should always be accompanied by a clear vision for future clinical application.

Acknowledgments The authors are grateful to Timothy Ganey for his contributions to the manuscript.

Open Access This article is distributed under the terms of the Creative Commons Attribution Noncommercial License which permits any noncommercial use, distribution, and reproduction in any medium, provided the original author(s) and source are credited.

\section{References}

1. Acaroglu ER, Iatridis JC, Setton LA et al (1995) Degeneration and aging affect the tensile behavior of human lumbar anulus fibrosus. Spine 20(24):2690-2701. doi:10.1097/00007632-1995 12150-00010

2. Adams MA, Hutton WC (1985) Gradual disc prolapse. Spine 10(6):524-531. doi:10.1097/00007632-198507000-00006

3. Ahlgren BD, Lui W, Herkowitz HN, Panjabi MM, Guiboux JP (2000) Effect of anular repair on the healing strength of the intervertebral disc: a sheep model. Spine 25(17):2165-2170. doi:10.1097/00007632-200009010-00004

4. Alini M, Li W, Markovic P et al (2003) The potential and limitations of a cell-seeded collagen/hyaluronan scaffold to engineer an intervertebral disc-like matrix. Spine 28(5):446454. doi:10.1097/00007632-200303010-00007 
5. Alini M, Roughley PJ, Antoniou J, Stoll T, Aebi M (2002) A biological approach to treating disc degeneration: not for today, but maybe for tomorrow. Eur Spine J 11(Suppl 2):S215-S220

6. Andersson GB, An HS, Oegema TR Jr, Setton LA (2006) Directions for future research. J Bone Joint Surg Am 88(Suppl 2):110-114. doi:10.2106/JBJS.F.00030

7. Atlas SJ, Keller RB, Wu YA, Deyo RA, Singer DE (2005) Long-term outcomes of surgical and nonsurgical management of sciatica secondary to a lumbar disc herniation: 10 year results from the maine lumbar spine study. Spine 30(8):927-935. doi: 10.1097/01.brs.0000158954.68522.2a

8. Atlas SJ, Keller RB, Wu YA, Deyo RA, Singer DE (2005) Long-term outcomes of surgical and nonsurgical management of lumbar spinal stenosis: 8 to 10 year results from the maine lumbar spine study. Spine 30(8):936-943. doi:10.1097/01.brs. 0000158953.57966.c0

9. Bajanes G, Perez A, Diaz M (2007) One year follow up of discectomy patients who received a mesh to repair the annulus fibrosus, vol 7. Spine Arthroplasty Society, Berlin

10. Battie MC, Videman T (2006) Lumbar disc degeneration: epidemiology and genetics. J Bone Joint Surg Am 88(Suppl 2):3-9. doi:10.2106/JBJS.E.01313

11. Best BA, Guilak F, Setton LA et al (1994) Compressive mechanical properties of the human anulus fibrosus and their relationship to biochemical composition. Spine 19(2):212-221

12. Bourgeault C, Beaubien B, Griffith S (2007) Biomechanical assessment of annulus fibrosus repair with suture tethered anchors. Spine Arthroplasty Society, Berlin

13. Bron JL, van Royen BJ, Wuisman PI (2007) The clinical significance of lumbosacral transitional anomalies. Acta Orthop Belg 73(6):687-695

14. Bruehlmann SB, Rattner JB, Matyas JR, Duncan NA (2002) Regional variations in the cellular matrix of the annulus fibrosus of the intervertebral disc. J Anat 201(2):159-171. doi:10.1046/ j.1469-7580.2002.00080.x

15. Cao L, Guilak F, Setton LA (2007) Three-dimensional morphology of the pericellular matrix of intervertebral disc cells in the rat. J Anat 211(4):444-452

16. Carragee EJ, Han MY, Suen PW, Kim D (2003) Clinical outcomes after lumbar discectomy for sciatica: the effects of fragment type and anular competence. J Bone Joint Surg Am 85-A(1):102-108

17. Cassidy JJ, Hiltner A, Baer E (1989) Hierarchical structure of the intervertebral disc. Connect Tissue Res 23(1):75-88. doi: $10.3109 / 03008208909103905$

18. Cauthen J (1999) Microsurgical reconstruction (annuloplasty) following lumbar discectomy: preliminary report of a new technique. Proceedings of the AANS/CNS joint section on spine and peripheral nerves, Orlando

19. Chang G, Kim HJ, Kaplan D, Vunjak-Novakovic G, Kandel RA (2007) Porous silk scaffolds can be used for tissue engineering annulus fibrosus. Eur Spine J 16(11):1848-1857. doi:10.1007/ s00586-007-0364-4

20. Chou AI, Bansal A, Miller GJ, Nicoll SB (2006) The effect of serial monolayer passaging on the collagen expression profile of outer and inner anulus fibrosus cells. Spine 31(17):1875-1881. doi:10.1097/01.brs.0000229222.98051.9a

21. Chou AI, Reza AT, Nicoll SB (2008) Distinct intervertebral disc cell populations adopt similar phenotypes in three-dimensional culture. Tissue Eng Part A 14:2079-2087

22. Choy DS (2000) Familial incidence of intervertebral disc herniation: an hypothesis suggesting that laminectomy and discectomy may be counterproductive. J Clin Laser Med Surg 18(1):29-32

23. Dai LY, Zhou Q, Yao WF, Shen L (2005) Recurrent lumbar disc herniation after discectomy: outcome of repeat discectomy. Surg Neurol 64(3):226-231. doi:10.1016/j.surneu.2004.11.003
24. Derderian CA, Bastidas N, Lerman OZ et al (2005) Mechanical strain alters gene expression in an in vitro model of hypertrophic scarring. Ann Plast Surg 55(1):69-75. doi:10.1097/01.sap. 0000168160.86221.e9

25. Duncan NA (2006) Cell deformation and micromechanical environment in the intervertebral disc. J Bone Joint Surg Am 88(Suppl 2):47-51. doi:10.2106/JBJS.F.00035

26. Edwards WT, Ordway NR, Zheng Y et al (2001) Peak stresses observed in the posterior lateral anulus. Spine 26(16):17531759. doi:10.1097/00007632-200108150-00005

27. Elfervig MK, Minchew JT, Francke E, Tsuzaki M, Banes AJ (2001) IL-1beta sensitizes intervertebral disc annulus cells to fluid-induced shear stress. J Cell Biochem 82(2):290-298. doi: 10.1002/jcb. 1153

28. Errington RJ, Puustjarvi K, White IR, Roberts S, Urban JP (1998) Characterisation of cytoplasm-filled processes in cells of the intervertebral disc. J Anat 192(Pt 3):369-378. doi:10.1046/ j.1469-7580.1998.19230369.x

29. Ethier DB, Cain JE, Yaszemski MJ et al (1994) The influence of anulotomy selection on disc competence. A radiographic, biomechanical, and histologic analysis. Spine 19(18):2071-2076. doi:10.1097/00007632-199409150-00012

30. Evans C (2006) Potential biologic therapies for the intervertebral disc. J Bone Joint Surg Am 88(Suppl 2):95-98. doi: 10.2106/JBJS.E.01328

31. Fazzalari NL, Costi JJ, Hearn TC et al (2001) Mechanical and pathologic consequences of induced concentric anular tears in an ovine model. Spine 26(23):2575-2581. doi:10.1097/0000 7632-200112010-00010

32. Feng H, Danfelter M, Stromqvist B, Heinegard D (2006) Extracellular matrix in disc degeneration. J Bone Joint Surg Am 88(Suppl 2):25-29. doi:10.2106/JBJS.E.01341

33. Floman Y, Millgram MA, Smorgick Y, Rand N, Ashkenazi E (2007) Failure of the Wallis interspinous implant to lower the incidence of recurrent lumbar disc herniations in patients undergoing primary disc excision. J Spinal Disord Tech 20(5):337-341. doi:10.1097/BSD.0b013e318030a81d

34. Ganey T, Libera J, Moos V et al (2003) Disc chondrocyte transplantation in a canine model: a treatment for degenerated or damaged intervertebral disc. Spine 28(23):2609-2620. doi: 10.1097/01.BRS.0000097891.63063.78

35. Garlet TP, Coelho U, Silva JS, Garlet GP (2007) Cytokine expression pattern in compression and tension sides of the periodontal ligament during orthodontic tooth movement in humans. Eur J Oral Sci 115(5):355-362. doi:10.1111/j.16000722.2007.00469.x

36. Gorensek M, Vilandecic M, Woburn (2007) Clinical investigation of intrinsic therapeutics Barricaid, a novel device for closing defects in the annulus. NASS 2006

37. Gruber HE, Fisher EC Jr, Desai B et al (1997) Human intervertebral disc cells from the annulus: three-dimensional culture in agarose or alginate and responsiveness to TGF-beta1. Exp Cell Res 235(1):13-21. doi:10.1006/excr.1997.3647

38. Gruber HE, Ingram JA, Norton HJ, Hanley EN Jr (2007) Senescence in cells of the aging and degenerating intervertebral disc: immunolocalization of senescence-associated beta-galactosidase in human and sand rat discs. Spine 32(3):321-327. doi: 10.1097/01.brs.0000253960.57051.de

39. Gruber HE, Leslie K, Ingram J, Norton HJ, Hanley EN (2004) Cell-based tissue engineering for the intervertebral disc: in vitro studies of human disc cell gene expression and matrix production within selected cell carriers. Spine J 4(1):44-55. doi: 10.1016/S1529-9430(03)00425-X

40. Gruber HE, Ma D, Hanley EN Jr, Ingram J, Yamaguchi DT (2001) Morphologic and molecular evidence for gap junctions and connexin 43 and 45 expression in annulus fibrosus cells 
from the human intervertebral disc. J Orthop Res 19(5):985989. doi:10.1016/S0736-0266(00)00072-3

41. Guerin HL, Elliott DM (2007) Quantifying the contributions of structure to annulus fibrosus mechanical function using a nonlinear, anisotropic, hyperelastic model. J Orthop Res 25(4):508516. doi:10.1002/jor.20324

42. Hakkinen A, Kiviranta I, Neva MH, Kautiainen H, Ylinen J (2007) Reoperations after first lumbar disc herniation surgery; a special interest on residives during a 5-year follow-up. BMC Musculoskelet Disord 8:2. doi:10.1186/1471-2474-8-2

43. Hampton D, Laros G, McCarron R, Franks D (1989) Healing potential of the anulus fibrosus. Spine 14(4):398-401. doi: 10.1097/00007632-198904000-00009

44. Hansson E, Hansson T (2007) The cost-utility of lumbar disc herniation surgery. Eur Spine J 16(3):329-337. doi:10.1007/ s00586-006-0131-y

45. Hegewald AA, Ringe J, Sittinger M, Thome C (2008) Regenerative treatment strategies in spinal surgery. Front Biosci 13:1507-1525. doi:10.2741/2777

46. Helder MN, Knippenberg M, Klein-Nulend J, Wuisman PI (2007) Stem cells from adipose tissue allow challenging new concepts for regenerative medicine. Tissue Eng 13(8):17991808. doi:10.1089/ten.2006.0165

47. Helen W, Gough JE (2007) Cell viability, proliferation and extracellular matrix production of human annulus fibrosus cells cultured within PDLLA/Bioglass(R) composite foam scaffolds in vitro. Acta Biomater 3:715-721

48. Helen W, Merry CL, Blaker JJ, Gough JE (2007) Threedimensional culture of annulus fibrosus cells within PDLLA/ Bioglass composite foam scaffolds: assessment of cell attachment, proliferation and extracellular matrix production. Biomaterials 28(11):2010-2020. doi:10.1016/j.biomaterials. 2007.01.011

49. Heuer F, Schmidt H, Wilke HJ (2008) The relation between intervertebral disc bulging and annular fiber associated strains for simple and complex loading. J Biomech 41:1086-1094

50. Holm S, Maroudas A, Urban JP, Selstam G, Nachemson A (1981) Nutrition of the intervertebral disc: solute transport and metabolism. Connect Tissue Res 8(2):101-119. doi:10.3109/ 03008208109152130

51. Hoogendoorn RJ, Lu ZF, Kroeze RJ et al (2008) Adipose stem cells for intervertebral disc regeneration: current status and concepts for the future. J Cell Mol Med (in press)

52. Horner HA, Roberts S, Bielby RC et al (2002) Cells from different regions of the intervertebral disc: effect of culture system on matrix expression and cell phenotype. Spine 27(10):10181028. doi:10.1097/00007632-200205150-00004

53. Humzah MD, Soames RW (1988) Human intervertebral disc: structure and function. Anat Rec 220(4):337-356. doi:10.1002/ ar.1092200402

54. Iatridis JC, ap Gwynn I (2004) Mechanisms for mechanical damage in the intervertebral disc annulus fibrosus. J Biomech 37(8):1165-1175. doi:10.1016/j.jbiomech.2003.12.026

55. Inkinen RI, Lammi MJ, Lehmonen S et al (1998) Relative increase of biglycan and decorin and altered chondroitin sulfate epitopes in the degenerating human intervertebral disc. J Rheumatol 25(3):506-514

56. Jahanyar J, Joyce DL, Southard RE et al (2007) Decorin-mediated transforming growth factor-beta inhibition ameliorates adverse cardiac remodeling. J Heart Lung Transplant 26(1):3440. doi:10.1016/j.healun.2006.10.005

57. Johnson EF, Chetty K, Moore IM, Stewart A, Jones W (1982) The distribution and arrangement of elastic fibres in the intervertebral disc of the adult human. J Anat 135(Pt 2):301-309

58. Johnson WE, Wootton A, El HA et al (2006) Topographical guidance of intervertebral disc cell growth in vitro: towards the development of tissue repair strategies for the anulus fibrosus. Eur Spine J 15(Suppl 3):S389-S396. doi:10.1007/s00586006-0125-9

59. Jonsson B, Stromqvist B (1993) Repeat decompression of lumbar nerve roots. A prospective two-year evaluation. J Bone Joint Surg Br 75(6):894-897

60. Kamaric E, Gorensek S, Trummer M et al (2007) Surgical factors affecting after lumbar discectomy: the need for an anular closure device. In Thera

61. Katz JN (2006) Lumbar disc disorders and low-back pain: socioeconomic factors and consequences. J Bone Joint Surg Am 88(Suppl 2):21-24. doi:10.2106/JBJS.E.01273

62. Key JA, Ford LT (1948) Experimental intervertebral-disc lesions. J Bone Joint Surg Am 30A(3):621-630

63. Kim JM, Lee SH, Ahn Y et al (2007) Recurrence after successful percutaneous endoscopic lumbar discectomy. Minim Invasive Neurosurg 50(2):82-85. doi:10.1055/s-2007-982504

64. Kluba T, Niemeyer T, Gaissmaier C, Grunder T (2005) Human anulus fibrosis and nucleus pulposus cells of the intervertebral disc: effect of degeneration and culture system on cell phenotype. Spine 30(24):2743-2748. doi:10.1097/01.brs.0000192204. $89160.6 \mathrm{~d}$

65. Korecki CL, Costi JJ, Iatridis JC (2008) Needle puncture injury affects intervertebral disc mechanics and biology in an organ culture model. Spine 33(3):235-241. doi:10.1097/BRS. 0b013e318175cae7

66. Laus M, Bertoni F, Bacchini P, Alfonso C, Giunti A (1993) Recurrent lumbar disc herniation: what recurs? (A morphological study of recurrent disc herniation). Chir Organi Mov 78(3): 147-154

67. Leung VY, Chan D, Cheung KM (2006) Regeneration of intervertebral disc by mesenchymal stem cells: potentials, limitations, and future direction. Eur Spine J 15(Suppl 3):S406S413. doi:10.1007/s00586-006-0183-z

68. Lotz JC, Kim AJ (2005) Disc regeneration: why, when, and how. Neurosurg Clin N Am 16(4):657-663, vii. doi:10.1016/ j.nec.2005.06.004

69. Lutolf MP, Hubbell JA (2005) Synthetic biomaterials as instructive extracellular microenvironments for morphogenesis in tissue engineering. Nat Biotechnol 23(1):47-55. doi:10.1038/ nbt 1055

70. Macri L, Silverstein D, Clark RA (2007) Growth factor binding to the pericellular matrix and its importance in tissue engineering. Adv Drug Deliv Rev 59(13):1366-1381. doi:10.1016/ j.addr.2007.08.015

71. Marchand F, Ahmed AM (1990) Investigation of the laminate structure of lumbar disc anulus fibrosus. Spine 15(5):402-410. doi:10.1097/00007632-199005000-00011

72. Masuda K, Takegami K, An H et al (2003) Recombinant osteogenic protein-1 upregulates extracellular matrix metabolism by rabbit annulus fibrosus and nucleus pulposus cells cultured in alginate beads. J Orthop Res 21(5):922-930. doi:10.1016/ S0736-0266(03)00037-8

73. McNally DS, Adams MA (1992) Internal intervertebral disc mechanics as revealed by stress profilometry. Spine 17(1):6673. doi:10.1097/00007632-199201000-00011

74. Meisel HJ, Siodla V, Ganey T et al (2007) Clinical experience in cell-based therapeutics: disc chondrocyte transplantation A treatment for degenerated or damaged intervertebral disc. Biomol Eng 24(1):5-21. doi:10.1016/j.bioeng.2006.07.002

75. Melrose J, Ghosh P, Taylor TK et al (1997) Elevated synthesis of biglycan and decorin in an ovine annular lesion model of experimental disc degeneration. Eur Spine J 6(6):376-384. doi: 10.1007/BF01834063

76. Melrose J, Smith SM, Appleyard RC, Little CB (2008) Aggrecan, versican and type VI collagen are components of annular 
translamellar crossbridges in the intervertebral disc. Eur Spine $\mathbf{J}$ 17(2):314-324. doi:10.1007/s00586-007-0538-0

77. Melrose J, Smith SM, Little CB et al (2008) Recent advances in annular pathobiology provide insights into rim-lesion mediated intervertebral disc degeneration and potential new approaches to annular repair strategies. Eur Spine J 17(9):1131-1148. doi: 10.1007/s00586-008-0712-z

78. Mizuno H, Roy AK, Vacanti CA et al (2004) Tissue-engineered composites of anulus fibrosus and nucleus pulposus for intervertebral disc replacement. Spine 29(12):1290-1297. doi: 10.1097/01.BRS.0000128264.46510.27

79. Moore RJ, Osti OL, Vernon-Roberts B, Fraser RD (1992) Changes in endplate vascularity after an outer anulus tear in the sheep. Spine 17(8):874-878. doi:10.1097/00007632-19920 8000-00003

80. Natarajan RN, Williams JR, Andersson GB (2004) Recent advances in analytical modeling of lumbar disc degeneration. Spine 29(23):2733-2741. doi:10.1097/01.brs.0000146471. 59052.e6

81. Nemoto Y, Matsuzaki H, Tokuhasi Y et al (2006) Histological changes in intervertebral discs after smoking and cessation: experimental study using a rat passive smoking model. J Orthop Sci 11(2):191-197. doi:10.1007/s00776-005-0987-4

82. Nerlich AG, Bachmeier BE, Schleicher E et al (2007) Immunomorphological analysis of RAGE receptor expression and NFkappaB activation in tissue samples from normal and degenerated intervertebral discs of various ages. Ann N Y Acad Sci 1096:239-248. doi:10.1196/annals. 1397.090

83. Nerlich AG, Schleicher ED, Boos N (1997) Volvo Award winner in basic science studies. Immunohistologic markers for age-related changes of human lumbar intervertebral discs. Spine 22(24):2781-2795. doi:10.1097/00007632-199712150-00001

84. Nerurkar NL, Elliott DM, Mauck RL (2007) Mechanics of oriented electrospun nanofibrous scaffolds for annulus fibrosus tissue engineering. J Orthop Res 25(8):1018-1028. doi: 10.1002/jor.20384

85. Osti OL, Vernon-Roberts B, Fraser RD (1990) 1990 Volvo Award in experimental studies. Anulus tears and intervertebral disc degeneration. An experimental study using an animal model. Spine 15(8):762-767. doi:10.1097/00007632-19900 8010-00005

86. Osti OL, Vernon-Roberts B, Moore R, Fraser RD (1992) Annular tears and disc degeneration in the lumbar spine. A postmortem study of 135 discs. J Bone Joint Surg Br 74(5):678-682

87. Paajanen H, Haapasalo H, Kotilainen E, Aunapuu M, Kettunen J (1999) Proliferation potential of human lumbar disc after herniation. J Spinal Disord 12(1):57-60. doi:10.1097/00002517199902000-00009

88. Perie D, Korda D, Iatridis JC (2005) Confined compression experiments on bovine nucleus pulposus and annulus fibrosus: sensitivity of the experiment in the determination of compressive modulus and hydraulic permeability. $\mathrm{J}$ Biomech 38(11):2164-2171. doi:10.1016/j.jbiomech.2004.10.002

89. Pezowicz CA, Robertson PA, Broom ND (2006) The structural basis of interlamellar cohesion in the intervertebral disc wall. $\mathrm{J}$ Anat 208(3):317-330. doi:10.1111/j.1469-7580.2006.00536.x

90. Postacchini F, Bellocci M, Massobrio M (1984) Morphologic changes in annulus fibrosus during aging. An ultrastructural study in rats. Spine 9(6):596-603. doi:10.1097/00007632198409000-00010

91. Rannou F, Lee TS, Zhou RH et al (2004) Intervertebral disc degeneration: the role of the mitochondrial pathway in annulus fibrosus cell apoptosis induced by overload. Am J Pathol 164(3):915-924

92. Rannou F, Richette P, Benallaoua M et al (2003) Cyclic tensile stretch modulates proteoglycan production by intervertebral disc annulus fibrosus cells through production of nitrite oxide. J Cell Biochem 90(1):148-157. doi:10.1002/jcb.10608

93. Reza AT, Nicoll SB (2008) Hydrostatic pressure differentially regulates outer and inner annulus fibrosus cell matrix production in 3D scaffolds. Ann Biomed Eng 36(2):204-213. doi: 10.1007/s10439-007-9407-6

94. Richardson SM, Knowles R, Marples D, Hoyland JA, Mobasheri A (2008) Aquaporin expression in the human intervertebral disc. $\mathrm{J}$ Mol Histol (in press)

95. Risbud MV, Guttapalli A, Tsai TT et al (2007) Evidence for skeletal progenitor cells in the degenerate human intervertebral disc. Spine 32(23):2537-2544

96. Roberts S, Evans EH, Kletsas D, Jaffray DC, Eisenstein SM (2006) Senescence in human intervertebral discs. Eur Spine J 15(Suppl 3):S312-S316. doi:10.1007/s00586-006-0126-8

97. Roberts S, Evans H, Trivedi J, Menage J (2006) Histology and pathology of the human intervertebral disc. J Bone Joint Surg Am 88(Suppl 2):10-14. doi:10.2106/JBJS.F.00019

98. Roughley PJ (2004) Biology of intervertebral disc aging and degeneration: involvement of the extracellular matrix. Spine 29(23):2691-2699. doi:10.1097/01.brs.0000146101.53784.b1

99. Rousseau MA, Ulrich JA, Bass EC et al (2007) Stab incision for inducing intervertebral disc degeneration in the rat. Spine 32(1):17-24. doi:10.1097/01.brs.0000251013.07656.45

100. Saad L, Spector M (2004) Effects of collagen type on the behavior of adult canine annulus fibrosus cells in collagen-glycosaminoglycan scaffolds. J Biomed Mater Res A 71(2):233241. doi:10.1002/jbm.a.30150

101. Sato M, Asazuma T, Ishihara M et al (2003) An experimental study of the regeneration of the intervertebral disc with an allograft of cultured annulus fibrosus cells using a tissue-engineering method. Spine 28(6):548-553. doi:10.1097/00007632200303150-00007

102. Sato M, Asazuma T, Ishihara M et al (2003) An atelocollagen honeycomb-shaped scaffold with a membrane seal (ACHMSscaffold) for the culture of annulus fibrosus cells from an intervertebral disc. J Biomed Mater Res A 64(2):248-256. doi: 10.1002/jbm.a.10287

103. Sato M, Kikuchi M, Ishihara M et al (2003) Tissue engineering of the intervertebral disc with cultured annulus fibrosus cells using atelocollagen honeycomb-shaped scaffold with a membrane seal (ACHMS scaffold). Med Biol Eng Comput 41(3):365-371. doi:10.1007/BF02348444

104. Schroeder Y, Sivan S, Wilson W et al (2007) Are disc pressure, stress, and osmolarity affected by intra- and extrafibrillar fluid exchange? J Orthop Res 25(10):1317-1324. doi:10.1002/ jor. 20443

105. Sebastine IM, Williams DJ (2007) Current developments in tissue engineering of nucleus pulposus for the treatment of intervertebral disc degeneration. Conf Proc IEEE Eng Med Biol Soc 1:6400-6405. doi:10.1109/IEMBS.2007.4353821

106. Setton LA, Chen J (2006) Mechanobiology of the intervertebral disc and relevance to disc degeneration. J Bone Joint Surg Am 88(Suppl 2):52-57. doi:10.2106/JBJS.F.00001

107. Shao X, Hunter CJ (2007) Developing an alginate/chitosan hybrid fiber scaffold for annulus fibrosus cells. J Biomed Mater Res A 82(3):701-710. doi:10.1002/jbm.a.31030

108. Sherman J, Cauthen J, Griffith S (2007) Pre-clinical evaluation of a mesh device for repairing the annulus fibrosus. Spine Arthroplasty Society, Berlin

109. Smith JW, Walmsley R (1951) Experimental incision of the intervertebral disc. J Bone Joint Surg Br 33-B(4):612-625

110. Smith LJ, Byers S, Costi JJ, Fazzalari NL (2008) Elastic fibers enhance the mechanical integrity of the human lumbar anulus fibrosus in the radial direction. Ann Biomed Eng 36(2):214-223. doi:10.1007/s10439-007-9421-8 
111. Smith LJ, Fazzalari NL (2006) Regional variations in the density and arrangement of elastic fibres in the anulus fibrosus of the human lumbar disc. J Anat 209(3):359-367. doi:10.1111/j.14697580.2006.00610.x

112. Stokes IA (1987) Surface strain on human intervertebral discs. J Orthop Res 5(3):348-355. doi:10.1002/jor.1100050306

113. Suk KS, Lee HM, Moon SH, Kim NH (2001) Recurrent lumbar disc herniation: results of operative management. Spine 26(6):672-676. doi:10.1097/00007632-200103150-00024

114. Sun DD, Leong KW (2004) A nonlinear hyperelastic mixture theory model for anisotropy, transport, and swelling of annulus fibrosus. Ann Biomed Eng 32(1):92-102. doi:10.1023/B: ABME.0000007794.87408.1e

115. Swartz KR, Trost GR (2003) Recurrent lumbar disc herniation. Neurosurg Focus 15(3):E10. doi:10.3171/foc.2003.15.3.10

116. Takegami K, An HS, Kumano F et al (2005) Osteogenic protein1 is most effective in stimulating nucleus pulposus and annulus fibrosus cells to repair their matrix after chondroitinase ABCinduced in vitro chemonucleolysis. Spine J 5(3):231-238. doi: 10.1016/j.spinee.2004.11.001

117. Taylor W (2006) Biologic collagen PMMA injection (artifill) repairs mid-annular concentric defects in the ovine model. Spine J 6(5S1):48S-49S

118. Urban JP, Holm S, Maroudas A, Nachemson A (1982) Nutrition of the intervertebral disc: effect of fluid flow on solute transport. Clin Orthop Relat Res (170):296-302

119. Videman T, Nurminen M (2004) The occurrence of anular tears and their relation to lifetime back pain history: a cadaveric study using barium sulfate discography. Spine 29(23):2668-2676. doi: 10.1097/01.brs.0000146461.27105.2b

120. Walmsley R (1953) The development and growth of the intervertebral disc. Edinburgh Med J 60(8):341-364

121. Wan Y, Feng G, Shen FH et al (2007) Novel biodegradable poly(1, 8-octanediol malate) for annulus fibrosus regeneration. Macromol Biosci 7(11):1217-1224. doi:10.1002/mabi. 200700053

122. Wan Y, Feng G, Shen FH, Laurencin CT, Li X (2008) Biphasic scaffold for annulus fibrosus tissue regeneration. Biomaterials 29(6):643-652. doi:10.1016/j.biomaterials.2007.10.031
123. Wang YH, Kuo TF, Wang JL (2007) The implantation of noncell-based materials to prevent the recurrent disc herniation: an in vivo porcine model using quantitative discomanometry examination. Eur Spine J 16(7):1021-1027. doi:10.1007/ s00586-007-0306-1

124. Wilda H, Gough JE (2006) In vitro studies of annulus fibrosus disc cell attachment, differentiation and matrix production on PDLLA/45S5 Bioglass composite films. Biomaterials 27(30):5220-5229. doi:10.1016/j.biomaterials.2006.06.008

125. Wilke HJ, Heuer F, Neidlinger-Wilke C, Claes L (2006) Is a collagen scaffold for a tissue engineered nucleus replacement capable of restoring disc height and stability in an animal model? Eur Spine J 15(Suppl 3):S433-S438. doi:10.1007/ s00586-006-0177-x

126. Yamazaki S, Banes AJ, Weinhold PS et al (2002) Vibratory loading decreases extracellular matrix and matrix metalloproteinase gene expression in rabbit annulus cells. Spine J 2(6):415-420. doi:10.1016/S1529-9430(02)00427-8

127. Yamazaki S, Weinhold PS, Graff RD et al (2003) Annulus cells release ATP in response to vibratory loading in vitro. J Cell Biochem 90(4):812-818. doi:10.1002/jcb.10681

128. Yeung AT, Yeung CA (2007) Minimally invasive techniques for the management of lumbar disc herniation. Orthop Clin North Am 38(3):363-372. doi:10.1016/j.ocl.2007.04.005

129. Yu J, Fairbank JC, Roberts S, Urban JP (2005) The elastic fiber network of the anulus fibrosus of the normal and scoliotic human intervertebral disc. Spine 30(16):1815-1820. doi:10.1097/01. brs.0000173899.97415.5b

130. Yu J, Tirlapur U, Fairbank J et al (2007) Microfibrils, elastin fibres and collagen fibres in the human intervertebral disc and bovine tail disc. J Anat 210(4):460-471. doi:10.1111/j. 1469-7580.2007.00707.x

131. Zhang Y, Anderson DG, Phillips FM et al (2007) Comparative effects of bone morphogenetic proteins and Sox 9 overexpression on matrix accumulation by bovine anulus fibrosus cells: implications for anular repair. Spine 32(23):2515-2520 